\title{
Inhibition of Renal Sympathetic Nerve Activity of Anesthetized Rats by Intracerebroventricular Administration of Angiotensin II
}

\author{
Xiu Ji Jin ${ }^{1, *}$, Hiroshi. Kannan ${ }^{1}$, Yoshiaki Hayashida ${ }^{2}$, Tadashi NAKamura ${ }^{2}$, \\ Hideaki HIGASHINO $^{1, * *}$ and Hiroshi YAMASHITA ${ }^{1, * * *}$ \\ 'Department of Physiology, School of Medicine, University of Occupational and Environmental Health, \\ Japan. Kitakyushu 807, Japan \\ ${ }^{2}$ Department of Systems Physiology, Institute of Industrial Ecological Sciences, University of Occupational and \\ Environmental Health, Japan. Kitakyushu 807, Japan
}

\begin{abstract}
Effects of intracerebroventricular (i. c. v.) administration of angiotensin II (AII) on renal sympathetic nerve activity (RSNA), arterial pressure, and heart rate were examined in rats anesthetized with a mixture of urethane and $\alpha$-chloralose. Administration of AII evoked an increase in arterial pressure and a decrease in RSNA with no significant change in heart rate. Prior $i$. c. v. administration of an AII antagonist, saralasin, greatly attenuated the pressor response and inhibition of RSNA induced by i. c. v. AII. Rats with sinoaortic denervation showed the same magnitude pressor response and decrease in RSNA as intact animals. The result suggests that central AII directly inhibits RSNA via AII specific receptors.
\end{abstract}

Key words: angiotensin II, renal sympathetic nerve activity, intracerebroventricular administration, rat.

(Received 11 August 1989, accepted 18 September 1989)

\section{Introduction}

Various lines of evidence suggest that angiotensin II (AII) participates in cardiovascular regulation and body water balance, not only by its direct effect on vascular smooth muscle and kidney, but also via its action on the central nervous system. Intracerebroventricular (i. c. v.) administration of AII induces release of vasopressin (AVP) and adrenocorticotropic hormones from the pituitary gland, drinking behavior and elevation of arterial pressure (Fitzsimons, 1980; Lang et al., 1983; Reid et al., 1982; Severs \& DanielsSevers, 1973). Furthermore, i. c. v. administration of AII evokes inhibition of renin secretion from the kidney (Lokhandwala et al., 1978; Malayan et al., 1979) and natriuresis (Brooks \& Malvin, 1982; Halperin et al., 1981; Unger et al., 1989). The mechanisms of centrally induced actions by AII have been extensively studied but have not been fully elucidated. The mechanisms of the pressor responses, inhibition of renin secretion and

\footnotetext{
*Permanent address: Xin Ji Jin, Department of Physiology, Yanbian Medical College, Yanji, Jilin Province, People's Republic of China.

**Permanent address: Hideaki Higashino, Department of Pharmacology, School of Medicine, Kinki University.

Sayama 589, Japan.

***T To whom correspondence should be addressed.
} 
natriuresis by AII have been suggested to consist of at least two components. It may be mediated by changes in sympathetic nerve activity (Falcon et al., 1978; Severs et al., 1966; Unger et al., 1981) and AVP release (Severs et al., 1970; Unger et al., 1981), but the relative significance of these mechanisms on the central AII-induced responses is still uncertain. Direct recording of nerve activity in the sympathetic nervous system after central administration of AII have been reported (Fukiyama, 1972; Keim \& Sigg, 1971; Severs \& Buckley, 1970; Tobey et al., 1983; Unger et al., 1985) but these studies have had conflicting results.

We, therefore, decided to reexamine the effects of i. c. v. AII on renal sympathetic nerve activity (RSNA) in anesthetized rats. The purpose of the present investigation is to: (1) quantitatively analyze the effects of i. c. v. AII on RSNA; (2) determine whether the AII induced responses were due to AII specific receptors; and (3) examine possible involvement of the baroreceptor reflex on the AII induced responses.

\section{Materials and Methods}

The experiments were carried out on rats which took standard laboratory rat chow and water ad libitum. Twenty-two male Wistar rats, weighing 450 and $580 \mathrm{~g}$, were anesthetized by intraperitoneal injection of a mixture of urethane $(700 \mathrm{mg} / \mathrm{kg})$ and $\alpha$-chloralose $(70 \mathrm{mg} / \mathrm{kg})$. This was supplemented during the experiment with one-fifth of the initial dose when necessary. The trachea was cannulated with a polyethylene tube. The left femoral artery and vein were cannulated for arterial pressure recording and for administration of drugs. Body temperature was maintained at $36-38^{\circ} \mathrm{C}$ by a heating pad. The rats were placed in a stereotaxic instrument according to the coordinates of Paxinos and Watson (1982). In 6 rats, arterial baroreceptor denervation was performed by bilaterally severing the glossopharyngeal nerves as close as possible to the foramen lacerum, the superior laryngeal nerves, the sympathetic chains below the superior cervical ganglions and the aortic nerves. Two rats also received bilateral transection of the cervical vagus nerves and were artificially respirated. Since there was no difference in responses between rats with intact vagus and vagotomized rats, the results were pooled. For cannulation of the lateral brain ventricle, a stainless steel guide cannula (O. D., $550 \mu \mathrm{m}$; length, $19 \mathrm{~mm}$ ) was used. Coordinates for the cannulation were: $0.8 \mathrm{~mm}$ posterior to bregma, $1.5 \mathrm{~mm}$ lateral to midline and $2.5 \mathrm{~mm}$ below the surface of the cortex. Stainless steel anchoring screws and dental acrylic cement were used to secure the cannula in place.

Through a midline abdominal incision, the left kidney was exposed and gently retracted to identify the renal nerves. The nerve branches were isolated from the renal artery, vein, and the surrounding connective tissue as far laterally as the kidney hilus. The nerve branches were crushed just proximal to their entry into the renal hilus, and the central ends of the crushed nerves were placed on bipolar silver wire electrodes. When an optimal nerve recording had been achieved, the nerves and the electrodes were covered with silicone rubber (Wacker Sil-gel 604), which was then allowed to harden. 


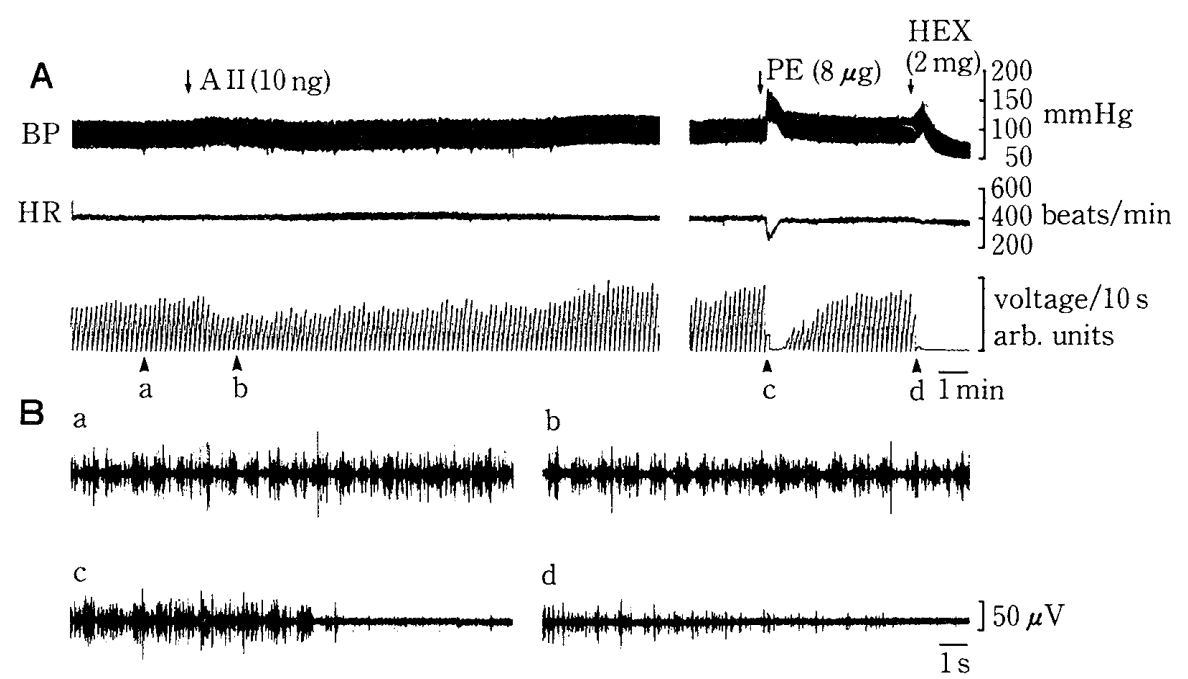

Fig. 1. Effects of intracerebroventricular (i. c. v.) administration of AII on arterial pressure, heart rate and renal sympathetic nerve activity. A: sample records of arterial pressure (BP), heart rate (HR) and integrated renal sympathetic nerve activity (RSNA). Increase in BP and decrease in RSNA with no significant change in HR evoked by i. c. v. AII (10 ng). The RSNA was completely abolished by intravenous administrations of phenylephrine chloride (PE, $8 \mu \mathrm{g})$ and hexamethonium chloride (HEX, $2 \mathrm{mg}$ ). B: recordings of the action potentials of the RSNA taken at $a, b, c$ and $d$ marked in $A$.

For measurement of RSNA, the neural signals were amplified by a differential preamplifier (WPI, MOD, DAM-5A) with high-and low-frequency cut off at 3000 and $100 \mathrm{~Hz}$, respectively. The action potentials were displayed on an oscilloscope and stored on magnetic tape for later analysis. The action potentials played back from the magnetic tape were recorded on a high-speed thermal recorder (Nihon Koden, WS-641G) and simultaneously fed to an integrator. The threshold level was set to filter the background noise remaining after injection of phenylephrine chloride $(4-8 \mu \mathrm{g}$, i. v.) or hexamethonium chloride (2-4 mg, i. v.) (Fig. 1). The integrated action potentials were reset every $10 \mathrm{~s}$ and displayed on the recorder, together with arterial pressure and heart rate.

For administration of AII into the i. c. v., a stainless steel injector (O. D., $300 \mu \mathrm{m}$ ) was introduced through the guide cannula and protruded $1 \mathrm{~mm}$ beyond the tip of the guide. The injector was connected via PE-10 tubing to a Hamilton microsyringe driven by a microdrive. Injected peptide volume was $1-2 \mu$. The peptides used in the experiments were AII and Sar', Ala ${ }^{8}$-angiotensin II (saralasin) which were purchased from the Peptide Institute, Minoh, Japan. The peptides were dissolved in normal saline.

After each experiment, Pontamine Sky Blue dye $(1 \mu l)$ was injected into the lateral ventricular cannula to verify that injections were actually in the ventricular system. The brain was removed, examined to ensure that the dye had reached the ventricular system, and cut into $40 \mu \mathrm{m}$ sections for histological examination after staining with neutral red.

Results are presented as Mean $\pm \mathrm{SE}$. For statistical evaluation, Student's t-test was used for paired and unpaired observations. A value of $P<0.05$ was considered significant. 


\section{Results}

To allow the recording electrodes to stabilize, tests were commenced approximately 3 hours after implantation. The systolic arterial pressure in the present experiments was 119 $\pm 4 \mathrm{mmHg}(\mathrm{n}=22)$.

Intracerebroventricular administration of AII (10 ng) increased arterial pressure and decreased RSNA with a latency of approximately $30 \mathrm{sec}$ after injection (Fig. 1). Heart rate did not change. A control injection of vehicle $(0.9 \% \mathrm{NaCl})$ did not significantly change the arterial pressure or RSNA. The time courses of changes are shown in Fig. 2. The maximum changes in arterial pressure appeared $1-2$ min after i. c. v. administration of AII, in RSNA they appeared in 2-5 min. The arterial pressure and RSNA returned to control level 15-30 min after administration. To examine dose-related responses, various doses from 0.01 to $100 \mathrm{ng}$ of AII were injected. The minimum interval between injections was 30 min to allow arterial pressure and RSNA to return to control levels. The results are shown in Fig. 3. The pressor response was dose-related except at high concentration (100 ng AII) and the larger the dose, the longer the time needed for recovery. Response in RSNA, however, was not clearly dose-related.
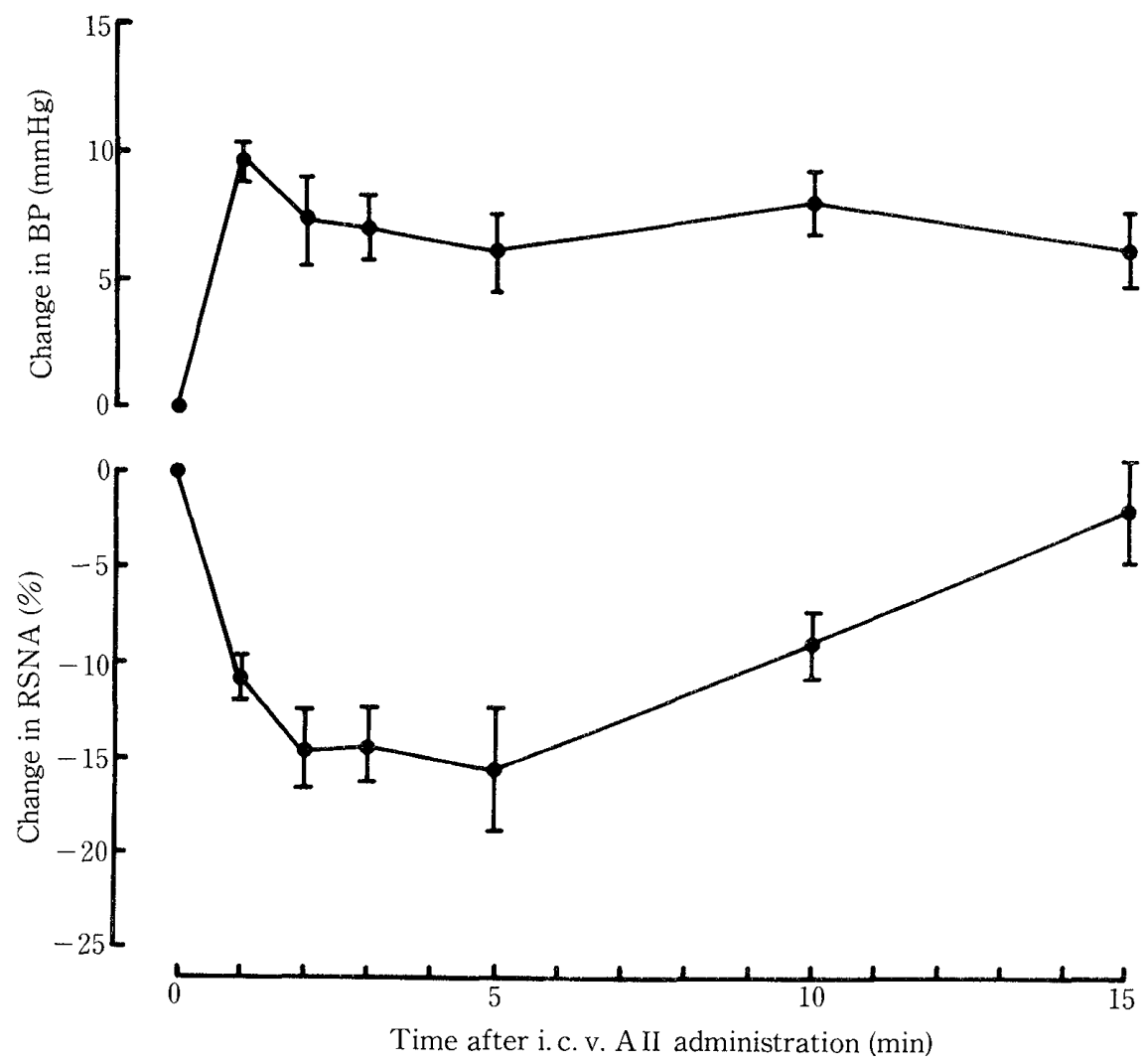

Fig. 2. Time courses of changes in arterial pressure (BP, upper panel) and renal sympathetic nerve activity (RSNA, lower panel) induced by i. c. v. administration of AII (10 ng) in intact rats $(\mathrm{n}=11)$. Values are Mean $\pm \mathrm{SE}$ 


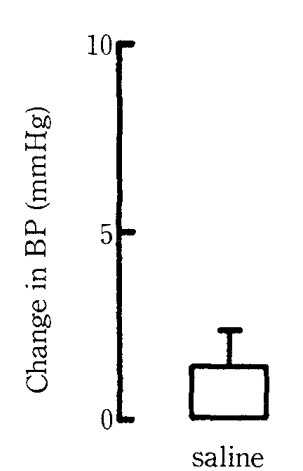

(9)

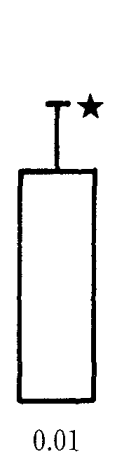

(4)

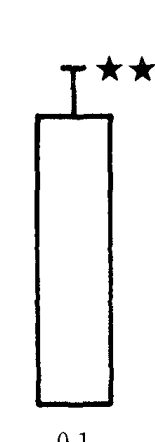

0.1

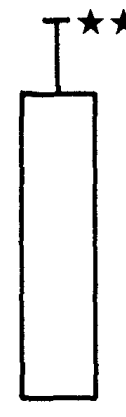

1

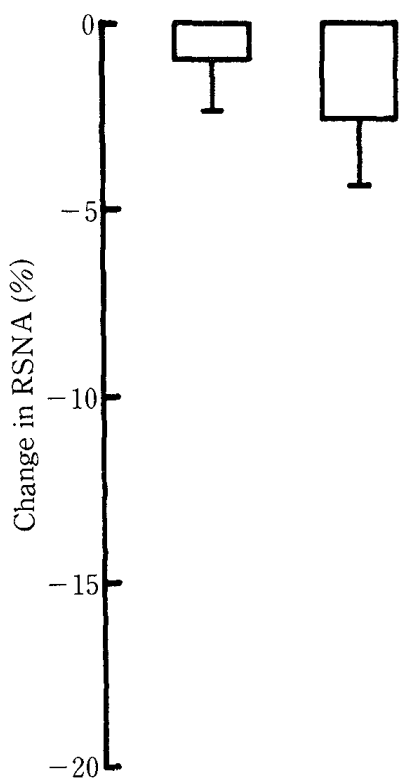

(5)

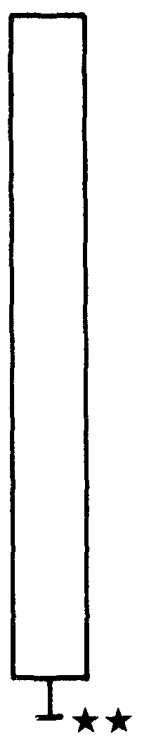

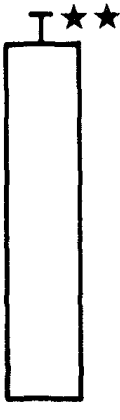

10

(11)

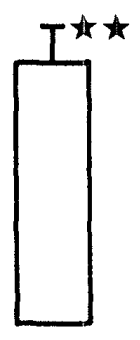

100 ng

(7)

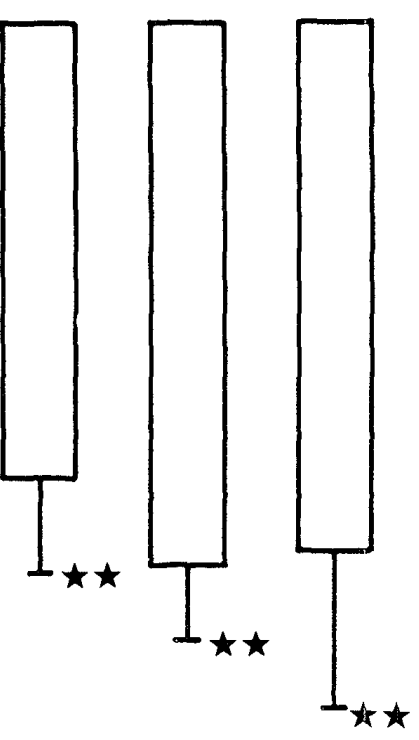

Fig. 3. Effects of i. c. v. administration of AII on arterial pressure (BP, upper panel) and renal sympathetic nerve activity (RSNA, lower panel). Doses injected were 0.01, 0.1, 1, 10 and 100 ng. Numbers in parenthesis show sample sizes. BP was measured 1 min after, and 60 sec average of RSNA was taken 2 min after administration. Values are Mean $\pm \mathrm{SE}$, compared to saline (Student's t-test) ${ }^{*} P<0.05,{ }^{* *} P<0.01$.

In another series of experiments $(n=5)$, effects of an AII antagonist, saralasin were tested. After the first i. c. v. administration of AII (control), recovery of the arterial pressure and RSNA changes were confirmed (after a minimum interval of $30 \mathrm{~min}$ ) and then each rat received saralasin (200 ng) $5 \mathrm{~min}$ prior to the second administration of AII. Administration of saralasin i. c. v. had no effect on basal arterial pressure or RSNA but greatly attenuated AII-induced pressor response and inhibitory response in RSNA (Fig. 4). Intravenous pre-treatment with the saralasin $(4 \mu \mathrm{g})$ did not affect central responses induced by AII.

To examine the possibility that RSNA inhibition was due to baroreceptor activation induced by increased arterial pressure, arterial baroreceptor-denervated (SAD) rats $(n=6)$ were used. In the SAD rats, the heart rate and RSNA response to i. v. phenylephrine $(4-8 \mu \mathrm{g})$ were abolished, indicating that the denervation was adequate. After i. c. v. 


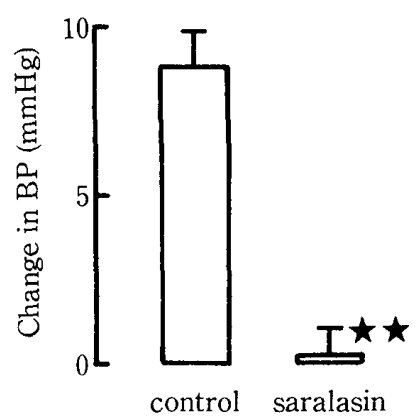

(5)

(5)

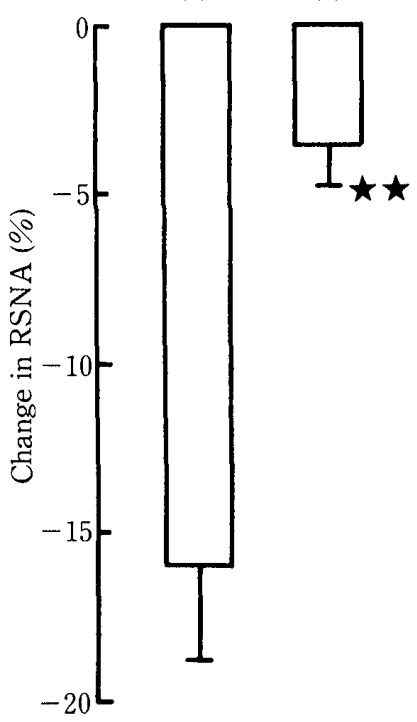

Fig. 4. Effects of i. c. v. administration of saralasin on changes in arterial pressure (BP, upper panel) and renal sympathetic nerve activity (RSNA, lower panel) induced by i. c. v. administration of AII (10 ng). Rats first received AII (left column). Saralasin (200 ng) was administered intracerebroventricularly $5 \mathrm{~min}$ prior to second i. c. v. administration of AII (right column). Values are Mean $\pm \mathrm{SE}(\mathrm{n}=5)$, compared to first administration of AII (Student's t-test) ${ }^{* *} P<0.01$.

administration of AII, the increase in arterial pressure and the decrease in RSNA persisted at the same magnitude as in the intact animals (Fig. 5).

\section{Discussion}

The present study demonstrated that intracerebroventricular administration of AII increased arterial pressure and decreased renal sympathetic nerve activity in anesthetized rats. The results agree well with those reported in conscious rats (Unger et al., 1985). We also found that the increase in arterial pressure and decrease in RSNA were greatly attenuated by i. c. v. pre-treatment with the AII specific receptor antagonist, saralasin, indicating that the responses were mediated via central AII specific receptors.

Sympathetic nerve activity is inhibited by baroreceptor activation when arterial pressure increases. Thus, the observed inhibition of RSNA after i. c. v. AII administration might be attributed to the baroreceptor reflex elicited by an increase in arterial pressure. 


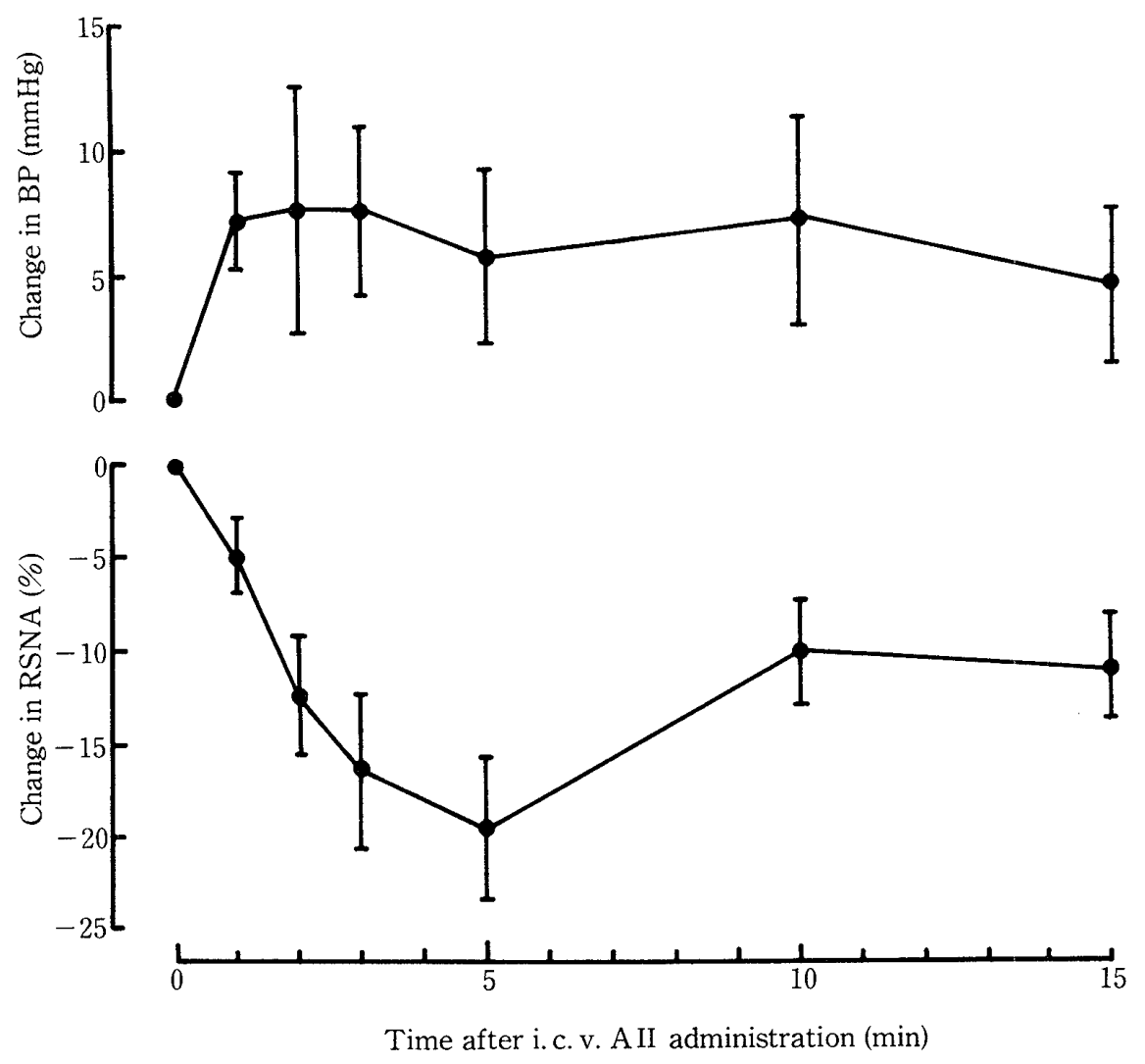

Fig. 5. Time courses of changes in arterial pressure (BP, Upper panel) and renal sympathetic nerve activity (RSNA, lower panel) induced by i. c. v. administration of AII (10 ng) in sinoaortic denervated rats $(n=6)$. Values are Mean $\pm S E$

However, the decrease in RSNA was still evoked in SAD rats, indicating that central AII directly inhibits renal sympathetic outflow.

In the present study, we could not completely exclude the possibility that the responses in arterial pressure and RSNA might be due to leakage of centrally administered AII into the systemic circulation. However, intravenous administration of saralasin did not affect the AII-induced central responses. The effects of i. c. v. administered AII on arterial pressure and RSNA lasted for approximately 15-30 min while the effect of the same intravenously injected dose on the arterial pressure lasted for only 2 min. Furthermore, it is also considered that AII, a polypeptide, does not freely cross the blood-brain barrier (Printz et al., 1982). Thus, the responses may have had a central origin.

The present result supports the hypothesis that central AII does not elicit generalized sympathetic activation but differentially affects the sympathetic outflow to different target organs (Tobey et al., 1983; Unger et al., 1985). Similarly regional differences in sympathetic outflow have been demonstrated following hypotensive hemorrhage (Victor et al., 1989) and central hyperosmotic stimulation (Tobey et al., 1983). It is likely that, in addition to AVP release, discrete and non-uniform increase in the sympathetic drive to other vascular territories, e. g. skeletal muscle, contributes to the pressor response to centrally administered AII. 
The physiological significance of central AII-induced inhibition of RSNA is not known. Circulating AII enhances renal sodium retention by stimulating aldosterone secretion. In contrast, i. c. v. administration of AII elicits natriuresis (Brooks \& Malvin, 1982; Halperin et al., 1981; Unger et al., 1989) and inhibition of renin secretion (Lokhandwala et al., 1978; Malayan et al., 1979). Thus, central and circulating AII have opposite actions on the renal control of sodium balance. It is generally accepted that RSNA directly affects the control of renal blood flow, renin release and urinary sodium excretion (DiBona, 1982). Since activation of the renal sympathetic nerve has been shown to increase sodium reabsorption from the renal tubules and renin release from the kidney, (Bello-Reuss et al., 1976; Coote et al., 1972; DiBona, 1977; Richardson et al., 1974) and to decrease renal blood flow (DiBona, 1982), the observed inhibition of RSNA may contribute in an important way to the central AII-induced natriuresis; directly through inhibition of sodium reabsorption and indirectly through inhibition of renin release and hemodynamic action. In order to examine the hypothesis, it is desirable directly to measure urinary sodium excretion as well as RSNA following i. c. v. administration of AII.

\section{Ackowledgment}

We thank Professor A. Simpson for help in the preparing this manuscript. We also thank Miss Sayuri Uesugi for preparing the manuscript. This work was supported by Grants-in-Aid for Scientific Research 62570078 and 63480118 from the Ministry of Education, Japan. X. J. Jin was supported by a WHO fellowship.

\section{References}

Bello-Reuss, E., Trevino, D. L. \& Gottschalk, C. W. (1976): Effect of renal sympathetic nerve stimulation on proximal water and sodium reabsorption. J. Clin. Invest., 57: 1104-1107.

Brooks, V. L. \& Malvin, R. L. (1982): Intracerebroventricular infusions of angiotensin II increases sodium excretion. Proc. Soc. Exp. Biol. Med., 169: 532-537.

Coote, J. H., Johns, E. J., Macleod, V. H. et al. (1972): Effect of renal nerve stimulation, renal blood flow and adrenergic blockade on plasma renin activity in the cat. J. Physiol., 226: 15-36.

DiBona, G. F. (1977): Neurogenic regulation of renal tubular sodium reabsorption. Am. J. Physiol., 233: F73-F81.

DiBona, G. F. (1982): The functions of the renal nerves. Rev. Physiol. Biochem. Pharmacol., 94: 75-181.

Falcon, J. C., Phillips, M. I., Hoffman, W. E. et al., (1978): Effects of intraventricular angiotensin II mediated by the sympathetic nervous system. Am. J. Physiol., 235: H392-H399.

Fukiyama, K. (1972): Central action of angiotensin and hypertension-increased central vasomotor outflow by angiotensin. Jap. Circ. J., 36: 599-602.

Fitzsimons, J. T. (1980): Angiotensin stimulation of the central nervous system. Rev. Physiol. Biochem. Pharmacol., 87: 117-167.

Halperin, E. S., Summy-Long, J. Y., Keil, L. G. et al. (1981): Aspects of salt/water balance after cerebroventricular infusion of angiotensin II. Brain Res., 205: 219-221.

Keim, K. L. \& Sigg, E. B. (1971): Activation of central sympathetic neurons by angiotensin II. Life Sci., 
10: $565-574$.

Lang, R. E., Unger, T., Rascher, W. et al. (1983): Brain angiotensin. In: Handbook of Psychopharmacology, vol. 16, (Iversen, L. et al., ed.). Plenum, New York. pp. 307-361.

Lokhandwala, M. F., Buckley, J. P. \& Jandhyala, B. S. (1978): Reduction of plasma renin activity by centrally-administered angiotensin II in anesthetized cats. Clin. Exp. Hypertension, 1: 167-175.

Malayan, S. A., Keil, L. C., Ramsay, D. J. et al. (1979): Mechanism of suppression of plasma renin activity by centrally administered angiotensin II. Endocrinology, 104: 672-675.

Paxinos, G. \& Watson, G. (1982): The Rat Brain in Stereotaxic Coordinates. Academic Press, Sydney.

Printz, M. P., Ganten, D., Unger, T. et al. (1982): Minireview: the brain renin angiotensin system. Exp. Brain Res., Suppl. 4: 3-52.

Reid, I. A., Brooks, V.L., Rudolph, C. D. et al. (1982): Analysis of the actions of angiotensin on the central nervous system of conscious dogs. Am. J. Physiol., 243: R82-R91.

Richardson, D., Stella, A., Leonetti, G. et al. (1974): Mechanisms of renal release of renin by electrical stimulation of the brainstem in the cat. Circ. Res., 34: 425-434.

Severs, W. B. \& Buckley, J. P. (1970): Spontaneous activity of the superior cervical nerve following central administration of angiotensin II. Pharmacology, 3: 187-190.

Severs, W. B., Daniels, A. E., Smookler, H. H. et al. (1966): Interelationship between angiotensin II and sympathetic nervous system. J. Pharmacol. Exp. Ther., 153: 530-537.

Severs, W. B. \& Daniels-Severs, A. E. (1973): Effects of angiotensin on the central nervous system. Pharmacol. Rev., 25: 415-449.

Severs, W. B., Summy-Long, J., Taylor, J. S. et al. (1970): A central effect of angiotensin: release of pituitary pressor material. J. Pharmacol. Exp. Ther., 174: 27-34.

Tobey, J. C., Fry, H. K., Mizejewski, C. S. et al. (1983): Differential sympathetic responses initiated by angiotensin and sodium chloride. Am. J. Physiol., 245: R60-R68.

Unger, T., Becker, H., Petty, M. et al. (1985): Differential effects of central angiotensin II and substance P on sympathetic nerve activity in conscious rats. Circ. Res., 56: 563-575.

Unger, T., Horst, P. J., Bauer, M. et al. (1989): Natriuretic action of central angiotensin II in conscious rats. Brain Res., 486: 33-38.

Unger, T., Rascher, W., Schuster, C. et al. (1981): Central blood pressure effects of substance P and angiotensin II: role of the sympathetic nervous system and vasopressin. Eur. J. Pharmacol., 71: 3342.

Victor, R. G., Thoren, P., Morgan, D. A. et al. (1989): Differential control of adrenal and renal sympathetic nerve activity during hemorrhagic hypotension in rats. Circ. Res., 64: 686-694. 
アンギオテンシン II の麻酔下ラット脳室内投与による腎交感神経活動の抑制反応

金 秀吉 ${ }^{1} \cdot$ 河南 洋 ${ }^{1} \cdot$ 林田 $\quad$ 嘉朗 $^{2} \cdot$ 中村 $\quad$ 正 $^{2} \cdot$ 東野 $\quad$ 英明 ${ }^{1} \cdot$ 山下 博 ${ }^{1}$

産業医科大学第一生理学教室

产業医科大学産業生態科学研究所応用生理学教室

要旨：アアンギオテンシン II （A II） は中枢性血圧上昇やナトリウム利尿作用を持つ。その機序とし ては，交感神経活動の関与が考えられているが，交感神経活動を直接記録して，脳室内投 与 A II の効果を調べた研究はまだ数少なく，またそれらの結果は一致していない。そここで， ウレタン・タロラロース麻酔したラットを用いて，側脳室内投与 A II の腎交感神経活動 (RSNA) に及ぼす効果を調べた，AII 投与によって，血圧上昇とRSNAの減少が見られた。 心拍数は有意な変化を示さなかった。これらの反応の閾值は $100 \mathrm{pg}$ であり，持続時間は 15ー30 分であったＡＩI の拮抗剤であるサララシンの前投与で，A IIによる反応は有意 に滅弱した．圧受容器からの求心性線維を切断したラットでも，正常ラットと同程度の A IIによるRSNA の抑制反応が見られた。これらの結果より，脳室内投与の A II は，AII リセプターを介して直接 RSNA を抑制すると結論される。

J. UOEH (産業医大誌), 11 ( 4): 361-370 (1989) 